\title{
HALK OPERETI TOPLULUĞU VE TÜRK MÜZIĞİ TARIHIINDEKİ YERİ Halk Opereti Topluluğu (Public Operetta Company) and its Place in Turkish Music History
}

Nihan ESKİTAŞ*

\begin{abstract}
ÖZ
Türklerde Batılı türler ile etkileşim, Osmanlı Devleti'nin batılllaşma politikası sürdüren padişahlar döneminde başlar ve devam eden süreçte, monarşik yapıya sahip olan Osmanlı Devleti'nde, kültürel, askeri, siyasal, sanatsal vb. her türden edimlerin de padişahların kişiliği ve idealleri doğrultusunda şekillendiği görülür. İlk defa III. Selim döneminde opera sahnelenen Osmanlı Devleti'nde, Tanzimat Dönemi'nden itibaren her türden Batılı müzikli tiyatro türünün sahnelendiğine kaynaklardan ulaşılabilmektedir. Zaman içinde operet türünde de temsillerin verildiği görülmektedir. Bu temsillerin gittikçe yoğunlaşması ve neredeyse halkın tek eğlence aracı olması sebebiyle, oldukça rağbet gördüğü anlaşılmaktadır. Popüler kültür ögesi haline gelen Operetlerin ve bu temsillerde icra edilen şarkıların, büyük bir seyirci kitlesinin müziksel alışkanlığına dönüşmesi, müziksel edimlere ve dolayısıyla da Türk müziğine etkisi olabileceği düşünülerek bu dönemde kurulmuş operet toplulukları incelenmiştir. Tarihsel yöntemle Avrupa'daki ve Osmanlı Devleti'ndeki gelişimi bakımından opera ve operet türleri ile ilgili bilgiler verilen makalede, karşılaştırma yöntemiyle diğer operet toplulukları ile Halk Opereti Topluluğu arasında benzerlikler ve farklılıklar ortaya konmuş, müziksel yoruma izin veren verilerden faydalanılarak Türk müziği tarihi açısından Halk Opereti Topluluğu'nun yeri tartışılmıştır.
\end{abstract}

Anahtar Kelimeler: Operet, Türk Opereti, Batılılaşma, Türk Müziği, Opera

\begin{abstract}
Interaction with Western genres in Turks, begins with the sultans of the Ottoman Empire who adopted westernization policy and in the ongoing process, it is seen that all kinds of acts_cultural, military, political and artistic _ were shaped in line with the personality and ideals of the sultans in the Ottoman Empire with a monarchical structure. The resources reveal that all types of Western music theater genres had been performed since the Tanzimat period in the Ottoman Empire where the first opera was performed during Selim III's sultanate. It is seen that opera performances came into question in the course of time. Being the only entertainment of the people, it is understood that these performances became very popular for the day. The operetta communities founded during this period were examined taking into consideration that the operettas' turning into a popular cultural element and their songs sang in these performances becoming the musical habit of a large audience may have affected Turkish music and its performances. In the article which gives information about the opera and operetta types in terms of their development in Europe and Ottoman Empire by historical method, the similarities and differences between the Halk Opereti Topluluğu (Public Operetta Company) and the other operetta groups were demonstrated by comparison method, the company's place in the Turkish music history was discussed using the data that allows musical interpretation.
\end{abstract}

Keywords: Operetta, Turkish Operetta, Westernization, Turkish Music, Opera

Araştırma Makalesi - Geliş Tarihi/Received Date: 07.11.2018, Kabul Tarihi/Accepted Date: 30.11.2018

*Sorumlu Yazar/Corresponding Author: Arş. Gör., Ege Üniversitesi, Sosyal Bilimler Enstitüsü, Temel Bilimler Anabilim Dalı, Türk Müziği Bölümü. nihan.viyola@hotmail.com. ORCID ID: https://orcid.org/0000-0003-4367-7663

Atıf/Citation: Eskitaş, N. (2018). Halk Opereti Topluluğu ve Türk müziği tarihindeki yeri. Eurasian Journal of Music and Dance, (13),82100 . 


\section{Extended Abstract}

This article focuses on the analysis and evaluation of the operetta songs performed by the Halk Opereti Topluluğu (Public Operetta Company) which was mentioned as the most popular operetta group of the early republican period in terms of Turkish music.

During the period of the Halk Opereti Topluluğu existed (1935-1953), technological innovations like television, radio, and cinema were not introduced to the Ottoman people and the people's only fun was to watch traditional theatre as tuluat, karagöz and Western musical theatre as operas, operettas and revues which they had met newly. In this article, the influence of the opera on the musical habits of the people was discussed on the ground that it became a trend during this period and it was almost the only entertainment of the people.

This article looks for the answers of the questions such as "When and how the operetta communities entered Turkish culture?", "Whether the songs of the operetta communities were composed by the rules of Turkish music system?", "Whether the opera songs of the Halk Opereti Topluluğu were composed by Western or Turkish music rules?" and "Whether the Halk Opereti Topluluğu and other operetta communities had an impact on Turkish music?".

In the article, which evaluates the social and cultural acquisitions in terms of their impact on Turkish music cultural connections were mentioned, cultural changes were determined with historical approach and the influence of all operetta communities on Turkish music was discussed by comparison method. In the methodology of the article; sources on the theatre and opera history, newspaper clippings, news and posters taken from the online archives of Cumhuriyet newspaper were benefited from. The first detailed information about Halk Opereti Topluluğu which is at the focal point of the article were compiled, analysis and conclusions were made by examining the musical comments in newspaper clippings because the voice recordings or scores of the community's operetta songs couldn't be reached.

The art of operetta is a sub-genre of opera according to the sources of the theatre and opera history and it entered to the culture of the Ottoman Empire thanks to the effects of the Westernization policies. In all sources, the art of operetta_an aristocratic habit initially_ was transformed into the cultural and social habits of the common people in time, as in all over the world.

Opera in the Turks, was watched by Selim III for the first time and the first Turkish operetta titled as Arif'in Hilesi was composed by Dikran Çuhaciyan in 1874. The operettas played at the Osmanll Opera Tiyatrosu (Ottoman Opera Theater) founded by Dikran Çuhaciyan led to a competition between him and Güllü Agop, the director of another famous theater building (Gedikpaşa Theater). This accelerated the spread of the operetta art. In time, the operettas began to be composed by the rules of Turkish music, and the national operettas were composed by important musicians of the period such as Muallim İsmail Hakkı Bey, Kaptanizade Ali Rıza Bey, Muhlis Sabahattin Ezgi and Leon Hanciyan. Muhlis Sabahattin's harmonization and hybridization that he used in the operetta songs by synthesizing western and Turkish music were continued by musicians as Cemal Reşit Rey. Later on, the Western music system's rules were applied when composing the operetta songs. This was an impact of Atatürk's music policy.

Halk Opereti Topluluğu, together with other operetta communities, fulfilled the need for public entertainment and they were satisfied with popularizing Western music as if tasked jointly. This was deduced from the community's composers' Western music education backgrounds and musical interpretations of the operetta songs in newspaper clippings. 
İlk olarak ilkel toplumların dini ritüellerinde bir edim olarak karşılaştığımız müzik, çağlar içinde evrilmiş, insanlığın her türden gelişimiyle kol kola gelişim göstermiş ve ulusallaşmış, türlere ayrılmış, her toplumda farklı sistemler ve formlar edinmiştir.

Opera, Batı Avrupa'da aristokrat zümreye hitap eden müzikli ve uzun soluklu (günlerce sürebilen) bir tiyatro türü olarak, müzikli ve uzun soluklu bir tiyatro türü olarak sahnelenen misterelerin din dışı konulara yönelimle ve aydınların öncülüğünde oluşmuştur. İtalya'nın Floransa kentinde ilk opera örnekleri verilen opera sanatı, kısa bir süre içinde süre olarak daha kısa, içinde güldürü-yergi gibi unsurların da bulunduğu alt türlere ayrılmış ve bu süreç sonucunda operet sanatı doğmuştur. Operet, ilk olarak Fransa'da Offenbach'ın besteleriyle tanınmış ve tıpkı opera gibi kısa sürede tüm Avrupa'ya yayılmıştır.

Avrupa'da yaşanan kültürleşmeye benzer olarak, sürdürülen batıllıaşma politikası sebebiyle Osmanlı Devleti'nde kültürlenme yaşanmış ve kısa sürede batılı yenilikler kendini göstermiş̧ir. Devletin ilk önce askeri alanda batılılaşması ve batılı çalgılardan meydana gelen bir bando kurması ile başlayan bu değişim, devletin her türden kurum ve kuruluşuna ve sosyal yaşamdaki her türden faaliyete kadar etki etmeye başlamıştır. İlk opera temsili, III. Selim döneminde izlenmiş, ilerleyen süreçte opera toplulukları kurulup yeni tiyatro binaları yaptırılmıştır. Saray ve çevresinin kültürüne işleyen opera sanatı toplulukların çoğalması ile halka da ulaşmış, halk tarafindan da benimsenmiştir.

Tanzimat döneminin yenileşme akımının da etkisiyle halkça da benimsenen batılılaşma, Meşrutiyet döneminde operet topluluklarının da kurulmasıyla devam etmiştir. İlk operet, Dikran Çuhacıyan tarafından ortaya konmuştur. Çok beğenilen "Arif'in Hilesi" adlı bu operet sebebiyle diğer tiyatrolarda sahnelenen müzikli oyunlara operet türü de dahil edilmiştir. Böylelikle ulusal operet örnekleri bestelenmeye başlamış ve Türk opereti dönemiyle batılı anlamda operet bestelenmesine gidecek yolda ilk adımlar atılmıştır.

Cumhuriyet dönemine gelindiğinde de operet topluluklarının temsilleri halkın neredeyse tek eğlencesi konumundadır ve özel operet toplulukları içinde Halk Opereti Topluluğu da çok rağbet görmüş fakat buna rağmen isminden pek az bahsedilmiş bir özel operet topluluğu olarak karşımıza çıkmaktadır. Türkiye'de turneler düzenleyerek, her zaman hınca hınç seyirciye sahip olmuş bir topluluk olarak ifade edilen ve döneminin en çok sevilen operet topluluğu olduğu iddia edilen topluluğun, tüm yurtta etkisinin olduğu düşünülerek; temsil edilen operet eserlerinin müziksel etkisini ortaya koymak, Türk müziği tarihi bakımından önemli görülmüştür. Erken Cumhuriyet döneminin halkı tesiri altına alan pek çok operet topluluğunun kurulduğu bir dönem olduğu göz önüne alındığında; halkın müziksel alışkanlığı, duyumu, edimi bakımından tüm özel operet topluluklarının da Türk müziğine etkisi incelenmiştir.

\section{Opera ve Operet Türlerinin Tarihçesi}

\section{Opera ve Tarihçesi}

Latince'de opus olarak kullanılan ve "yapıt" anlamına gelen kelimeden türemiş olan "opera", İtalyanca bir kelimedir ve "yapıtlar" anlamına gelmektedir. Yener'e göre; libretto adı verilen bir çeşit tiyatro oyunu metni üzerine, özel olarak yazılmış ve sözleri şarkıcılarca çalgı eşliğinde icra edilmek amacıyla bestelenmiş yapıtlara opera denmektedir (Yener, 1991: 447). 
Opera sanat1, XVI. yüzyılda İtalya'nın Floransa kentinde doğmuştur. Şair Rinuccini'nin yadığı metni besteleyen Jacopa Peri, "Daphne" adlı eserle bu türün ilk örneğini vermiştir (1594). Müzikli dram (dramma per musica) adıyla anılmış olan tür, XVII. yüzyılın sonlarından itibaren "opera" adıyla anılmaya başlanmıştır (Ertekin, 2007: 7).

Kısa sürede tüm Avrupa ülkelerine yayılan opera türü hızla gelişim göstermiştir. Operanın Fransa ve İngiltere'de filizlenişi 1670'li yıllara, Almanya'da 1700'lü yılların sonrasına rastlar. Opera, yüzyıllar boyunca İtalyan müzikçilerin öncülüğünde gelişen bir sanat olarak kalmıştır. Fransa'da ilk opera XIV. Louis'in emriyle Jean Baptiste Lully tarafından bestelenmiş ve yine onun öncülüğünde Fransız kültürüne yerleşmiştir (Uygun, 2010: 5-6). XVIII. yüzyılda özellikle İngiltere'de ballad opera (halk müziğinin etkisiyle yazılmış komik operalar) çok rağbet görmeye başlar. Almanya'da singspiel adıyla anılan bu tür, Mozart'la daha da gelişir. Fransa'da ise aynı stildeki operalara opera comique denilmiştir (Uygun, 2010: 6).

XIX. yüzyılda, milliyetçilik akımının tüm dünyaya yayılmasıyla birlikte, opera sahnesinde yeri olan diğer sanatlarda da bu akımın etkileri görülmeye başlar. Böylece; daha zengin dekor, 1şık, kostüm, makyaj ile desteklenen yeni ve daha gelişmiş bir opera ile karşılaşılır. XX. yüzyılda ise; yeni klasizm ve yeni romantizm akımının etkileriyle, bestecilerin yeniyi arama ve denenmemişi deneme yaklaşımlarıyla opera, müziksel ögeler bakımından zıtlıklar içeren iki ayrı bestecinin bestelerini birleştirdiği sahnelere değin sınırlarını açar.

\section{Operet ve Tarihçesi}

Fransızca opérette, hafif opera, müzikal tiyatro anlamında kullanılan Fransızca sözcük, İtalyanca aynı anlama gelen operetta sözcüğünden alıntıdır. Bu sözcükteki -etta eki, İtalyanca'da küçültme eki olarak kullanılır (Kutluk, 1989: 1).

XVIII. yüzyılda Paris'te ortaya çıkan operet sanatı, kısa opera, küçük opera, komik ve kısa opera olarak tanımlanabilecek olan ve olayları gülünç yanlarıyla, toplumsal ve siyasal yergi ögeleri kullanarak müzik eşliğinde sunan bir türdür. Opera'dan, müziğinin, dansının, konusunun daha basit, daha süssüz, daha az sanat kaygısıyla ve halka hitap etmek için bestelenmiş, düzenlenmiş ve yazılmış olmasıyla ayrılan operet, müzikal türünden de yergi ögesi taşıyor olması ve mutlaka güldürü ögeleri içermesi bakımından ayrılır.

Operet türünün ortaya çıkışına zemin hazırlayan gelişmeler, opera türünde oluşan bölünmeler sırasında olur ve operetler XVIII. yüzyılda küçük ve basit opera anlamındayken, XIX. yüzyılda Paris ve Viyana gibi iki sanat şehrindeki gelişimlerinden sonra bir sahne yapıtı olarak kabul edilmiştir. "Operada müzikal anlatım ön plandayken, operette teatral anlatım esere hakimdir." (Utku, 2005: 8).

\section{Osmanlı Devleti'nde Opera ve Operet}

Türklerin operayla tanışması, ilk olarak kavramsal boyutta gerçekleşmiştir ve Osmanlı İmparatorluğu dönemine denk gelmektedir. Somut anlamda opera sanatının Osmanlı Devleti'ne girdiği yıl, III. Selim'in Topkapı Sarayı'na getirttiği Avrupalı bir opera topluluğunun temsilini izlediği yıl olan 1797'dir (Yöre, 2008: 57).

III. Selim ve ondan sonra tahta geçen padişahlar, Osmanlı Devleti'nde batılılaşma ideolojisi sürdürmüştür. Bu politika sebebiyle Batı etkisi, her alanda olduğu gibi müzik alanında da kendini göstermişstir. II. Mahmut'un 1826'da Mehterhane'yi kapatıp, yerine batılı çalgılardan oluşan Muzıka-yı Humayun'u kurması ve bu bandonun 
başına İtalyan hoca (Donizetti) getirtmesi sarayda batı müziğine ilgiyi arttırmıştır. Ayrıca Muzıka-yı Humayun'un halka açık alanlarda düzenlenen her türden törende icrada bulunması ve bandonun repertuvarının polkalar, marşlar ve valslerden oluşmuş olması da çok sesli müziğe halkın da alışmasını kolaylaştırmıştır.

1839'da Tanzimat Fermanı'nı ilan eden II. Mahmut döneminin çalışmamız bakımından diğer önemli gelişmesi ise; sarayda yapılan faslın Fasl-1 Atik (Eski Fasıl) ve Fasl-1 Cedid (Yeni Fasıl) olarak ikiye ayrılmasıdır. Fasl-1 Cedid'in repertuvarı, köçekçe ve oyun havalarının armonize edilmiş şeklinden oluşmaktadır; ayrıca Türk ve batı çalgılarıyla çalınmışlardır. Muzıka-yı Humayun'un içindeki hanendelerden kurulu bu fasıl grupları içerisinde batı müziği icra eden hanendeler, daha sonraki dönemlerde opera, operet gibi batı türlerini de icra etmişlerdir (Özcan, 2006: 423). Bu dönemde Osmanlı Devleti'nin müzik zevkinde değişiklik olmaya başlamış, operet ve vodvil gibi müzikli sahne sanatları önem kazanmaya başlamıştır.

II. Mahmut, Fransız Tiyatrosu'nu (ilk özel tiyatro ve opera binası) da destekleyerek, tiyatro ve opera temsillerinin saray dışındaki tek mekanı olan bu tiyatro binasında Fransız komedi ve operet gruplarının temsiller vermesine de destek vermiştir (Sevengil, 1959: 18).

Abdülmecid döneminde (1839-1861) tiyatro binalarının sayısında artış olması, padişahın bunu desteklemesi, operetlere daha geniş bir saha tanımıştır. Bu dönemde sarayda erkeklerden oluşan bir fanfar ekibinin yanında, kızlardan oluşan bir fanfar ekibi de oluşturulur. Kız bale ekibinin temsillerinde, kızlardan oluşan fanfar ekibi müzik eşliği yapar. Bazı şenliklerde kızlardan kurulu fanfar takımı, opera parçaları çalmış, kız bale ekibi danslar yapmıştır: İskoçya ayak oyunları, İspanyol dansları, başka batılı tarzda danslar, türlü oyunlar ve pandomimler. Kızlardan kurulu fanfar takımı, La Traviata operasından parçalar da çalar. Orkestrada keman, viyolonsel ve kontrbas çalan kızlar bando takımında da yer alır (Saz, t.y.: 133), (Saz, 2000: 50). Muzıka-yı Humayun'dan genç aktör ve aktrisler de zaman zaman bazı saray eğlencelerinde, orkestra ile birlikte yer alır (Saz, t.y.: 132). Abdülmecid döneminde, sarayda meşkhanede keman, kemençe, vals, ve şan dersleri verildiğine dair belgeler bulunmaktadır (Toker, 2016: 142).

Abdülaziz'in 1876'da tahta çıkmasıyla, ekonomik kriz sebebiyle birtakım kısıtlamalara gidilmiştir. Müzikteki yansımaları, geleneksel müziği koruyup, batılı müziğin çalışmalarını durdurmak ve batılı orkestraları ortadan kaldırmak şeklinde görülen bu tasarruf döneminde, operet ve opera çalışmaları da durmuştur. 1863 tarihinden itibaren saray tiyatrosunda Muzıka-yı Humayun mensuplarının Türkçe tiyatro oynamaları da ciddiye alınmayıp, bu çalışmalar da durur. Bu dönemde, geleneğe bağlı saray eğlenceleri, cambazlık, cüceler, meddahlar ise; yeniden ilgi çeker, eski saray eğlencelerine rağbet artar (Sevengil, 1962: 49). Fakat; bu tasarruf hareketlerinin konumuz bakımından olumlu bir etkisi olur. Yazın ortaoyunu temsilleri için sahneye çıkıp, geçimini sadece yaz aylarında sağlayabilen ve kış geldiğinde kapalı salon olmadığg için başka işler yaparak geçimini sürdürmek zorunda kalan pek çok tiyatro sanatçısı, bir tiyatro binasında ortaoyunu temsillerine yaz-kış devam edebilmek için Gedikpaşa Tiyatrosu'nu kullanmaya başlar. Böylece Gedikpaşa Tiyatrosu, yalnızca aristokrasinin değil halkın da ilgisini çekmeye başlar ve bu da Gedikpaşa Tiyatrosu'nun müdürü konumundaki Güllü Agop ismiyle bilinen Agop Vartoviyan'ın Osmanlı halkını tiyatroya çekebilmek için Türkçe temsil verdirme hareketinde bulunmasıyla gerçekleşir. Pek çok yabancı opera ve operet truplarının gelip temsil verdiği Gedikpaşa Tiyatrosu'nda, Muzıka-yı Humayun'dan sanatçılar Türkçe temsiller, piyesler, dramlar, komedyalar sergiler ve bu tiyatro Türk tiyatro tarihinde önemli bir yer edinir. Tiyatro alanında çalışmalar yapmış olan pek çok araştırmacı, yazar tarafından Gedikpaşa Tiyatrosu, ilk ulusal tiyatro olarak görülür. Genellikle Fransız operetlerinin Türkçe'ye çevrilerek 
oynandığı Gedikpaşa Tiyatrosu'na, henüz Güllü Agop saray tiyatrosuna alınmadan (1882) önce önemli bir rakip çıkar. Güllü Agop padişahtan aldığı destekle vepek çok oyun türünü (komedya, dram, melodram, tragedya ve vodvil) oynatma tekelini elinde bulundurduğu için bu duruma itiraz eder, fakat; tüm çabalarına rağmen Dikran Çuhaciyan (1840-1898) ${ }^{1}$ isimli Ermeni asıllı opera bestecisinin, Dikran Kalemciyan ile birlikte Osmanlı Opera Tiyatrosu'nu kurmasına ve bu isimle opera ile operet temsilleri verdirmesine mani olamaz (1874) (Sevengil, 1961: 87). Osmanlı Devleti'nde Türkçe olarak oynanan ilk operet olma özelliğine sahip"Arif'in Hilesi"(1872- Dikran Çuhacıyan, Hosip Yazıcıyan) adlı operet, zaten Türkçe temsillere önem verilmekte olan Gedikpaşa Tiyatrosu'ndaki bir diğer ilk olma özelliği taşır. Güllü Agop'un sözleşmesindeki açıktan faydalanarak kurulan Osmanlı Opera Tiyatrosu'nun ilk operet temsili olan Arif'in Hilesi adlı operet (komik opera), ilk Türkçe operet olarak, ilk defa Gedikpaşa Tiyatrosu'nda 9 Aralık 1872 'de oynanır. Arif'in Hilesi, daha sonraları var olan tiyatro topluluklarınca da temsil edilir (Sevengil, 1961: 67).

II. Abdülhamid dönemine (1876- 1909) gelindiğinde, müzikli tiyatrolara ve özellikle batılı tiyatro türlerine ilgi artarak devam etmiştir. Bu iki alanı birleştiren bir kurum oluşturulur ve 1914 yılında, "Darülbedayi-i Osmani" (Darülbedayi) adında, tiyatro ve müzik eğitimi verecek bir kurum açılır. Bu kurum, Garb Musikisi ve Şark Musikisi bölümlerinin yanı sıra tiyatro bölümünü de içinde barındırmış, daha sonraları da Tatbikat Sahnesi adıyla yalnızca bir tiyatro topluluğunun adı haline gelmiştir. Darülbedayi'nin Cihan Harbi sonrasında "Darülelhan" (Nağmeler Evi) adıyla çalışmaları devam etmiştir. Maarif-i Umumiye Nezareti (bugünkü adı: Milli Eğitim Bakanlığı)'nin bir müzik danışma kurulu kurması ve bu danışma kurulunun hazırladığı talimatlar ve önerilerle açılmasına karar verilen Darülelhan, ilk olarak Cağaloğlu'nda, Himaye-i Eftal Sokağı'nda bir konakta çalışmalarına başlamış, sonraları da Şehzadebaşı'nda bu çalışmalarını sürdürmüştür (Özcan, 1993: 518-520).

22 Ocak 1927 tarihinde "İstanbul Musiki Konservatuvarı" adı altında İstanbul Şehremaneti’ne bağlanan Darülelhan, sonraları da "İstanbul Belediye Konservatuvarı" adıyla çalışmalarını sürdürmüştür. 1934 yılına gelindiğinde, bir yıldan kısa süren ve tüm kurum ve kuruluşlarda Türk müziği yasağı veya kısıtlamaları getirilmesine yol açan bir gelime yaşanır. M. Kemal Atatürk'ün sözlerinin yanlış yorumlanması sebebiyle Türk müziği yasağı gerçekleşmiştir ve kurumda da Türk müziği kısıtlamaları yaşanır:

Arkadaşlar! Güzel sanatların hepsinde, ulus gençliğinin ne türlü ilerletilmesini istediğinizi bilirim. Bu yapılmaktadır. Ancak, bunda en çabuk en önde götürülmesi gerekli olan Türk musikisidir (Alkışlar). Bir ulusun yeni değişikliğinde ölçü, musikide değişikliği alabilmesi, kavrayabilmesidir. Bugün dinletilmeye yeltenilen musiki yüz ă̆artacak dĕgerde olmaktan uzaktır. Bunu açıkça bilmeliyiz. (onay sesleri, alkışlar) Ulusal ince duyguları düşünceleri anlatan yüksek deyişleri, söyleyişleri toplamak onları bir gün önce genel musiki kurallarına göre işlemek gerektir. Ancak bu düzeyde, Türk ulusal musikisi yükselebilir, evrensel musikide yerini alabilir. Kültür işleri bakanlı̆̆ının buna değerince özen vermesini, kamunun da bunda ona yardımcı olmasını dilerim... (Cumhuriyet Ansiklopedisi, 1998, aktaran Ertekin, 2007: 53).

\footnotetext{
${ }^{1}$ Dikran Çuhacıyan: Türk müziğine orkestra düzenlemesi yaparak ve armoni, kontrpuan bilgisini de bu işe katarak beste yapan, Osmanlı’nın ilk çoksesli müzik bestecisi Dikran Çuhacıyan'ın en ünlü opereti Leblebici Horhor Ağa'dır. Çuhacıyan, Naum Tiyatrosu'nda İtalyan artistler tarafindan verilen opera temsillerini seyreder. Daha sonraları da Avrupalı ögretmenlerden müzik dersi alıp, devlet destekli olarak Milano Konservatuvarı'na giden ve ilk operalarını 1868 'de Ermenice olarak besteleyen Çuhacıyan, Osmanlı'daki ilk Türkçe opera (daha çok da operet) bestecisi olma vasfinı taşır (Yöre, 2011: 63).
} 
Atatürk'ün bu sözleri yanlış anlaşılmış veya yanlış anlaşılmak istenmiş ki, ertesi gün 2 Kasım 1934 'ten 6 Eylül 1936’ya dek sürecek bir yasaklama ile radyolarda Türk Musikisi çalınması yasaklanmıştı." (Ertekin, 2007: 53).

Darülbedayi ve Darülelhan gibi önemli kuruluşlar henüz kurulmamışken, halkın operet türüne alışmasını kolaylaştıran pek çok topluluk kurulmuştur. Yerli ve yabancı toplulukların temsillerinde, yabancı pek çok operetle karşılaşıldığı gibi, yerli operetlerle de tanışılır. Muallim İsmail Hakkı Bey, Subhi Ezgi (Bugün kullanılan Türk Müziği Sistemi'nin kurucularındandır.), Hasan Ferit Alnar, Cemal Reşit Rey, Leon Hancıyan, Kaptanizade Ali Rıza Bey (Macun Hokkası (Uslu, 2008, aktaran Uygun, 2010: 57) ve İstanbul Efendisi ünlü operetleridir.), Fahri Kopuz, Muallim Kazım Bey gibi isimlerin operet besteleri ile yerli operet bestelerine kavuşulur. Bahsi geçen isimler içinde, "Türk Opereti" olarak anılan, geleneksel Türk müziği sistemi içinde bestelenmiş ulusal operet ürünleri veren Muallim İsmail Hakkı Bey, Türk müziği açısından Türk operetlerinin yerinin saptanabilmesi için önemli görülmektedir. Ayrıca; Türk operetine besteciliğiyle katkısı olan Kaptanizade Ali Rıza Bey, Leon Hancıyan gibi isimlerin yanı sıra; batı müziği ve Türk müziği sentezlemesiyle öne çıkan bir diğer besteci olan Muhlis Sabahattin, bu dönem ve operet besteciliği açısından önemli görülmektedir.

\section{Muallim İsmail Hakkı Bey (1865-1927)}

Türk müziği kurallarına göre operet besteleyen ve Türk müziği sazlarından kurulu bir orkestra ile bu operetleri seslendiren İsmail Hakkı Bey'e ait 15 adet operet eseri bulunmaktadır. Bu eserler, Bülbül, Lale devri, Kaşıkçılar, Damat İbrahim Paşa,Yedekçi, Kiracılar, Narü's-sabah, Emel, Gazanfer, İyi saatte olsunlar, Gelin Kaynana, Falcı, Atll ases, Tutkun, Ve mine'l- Garaib, Cinci Hoca, isimli operetlerdir.

Operet eserlerinin Türk müziği sistemi kurallarına göre bestelenmiş olması, Türk müziği geleneksel çalgılarıyla icra edilmesi ve bu eserlerin operet temsillerinde sahnede icra edilmesi suretiyle İsmail Hakkı Bey, Türk müziğinin sahne müziği olarak kullanılmasına öncülük etmiştir.

\section{Leon Hanciyan (1860-1947)}

Meşrutiyet döneminin hem Türk müziği açısından hem de operet besteciliği açısından bir diğer önemli ismi olan Leon Hancıyan, İstanbul doğumlu olup, babasının odabaşısı olmasından kaynaklı bu soyadla anılır. Mektebi Tıbbiye (Tıp Okulu)'nin dördüncü sınıfından, müziğe duyduğu ilgi sebebiyle ayrılır ve hayatını müziğe adar. Sarayda ve Darülbedayi, Darülelhan gibi kurumlarda müzik öğretmenliği yapar, Mısır, Bulgaristan, Romanya'ya gider ve Batı müziği, Çin müziği, Japon müziği gibi farklı etnisite içindeki müzikler ile de ilgilenir. Piyano ve keman çalan Hancıyan, aynı zamanda bir ses icracısıdır. Müsahipzade Celal'in İstanbul Efendisi'ni besteler (Papazyan, 1975: 19-20).

\section{Kaptanizade Ali Rıza Bey (1881-1934)}

Meşrutiyet döneminin önemli bir operet topluluğu olan İstanbul Operet Heyeti adındaki topluluk, opera, marş, tango gibi batılı türlerde eserler veren ve Darülbedayi ve Darülelhan'da hocalık yapmış olan Kaptanizade Ali Rıza Bey'in yönetimindeki topluluktur. 1954'te kurulan topluluk, Türk müziği tarihi açısından önemli görülür çünkü; topluluğun temsillerinde Türk müziği kurallarına göre bestelenmiş operet şarkıları kullanılmıştır.

"Kaptanzade Ali Rıza Bey'in kurduğu İstanbul Operet Heyeti, yerli konularda geleneksel Türk müziğinden bestelenmiş çok ilginç eserler vermiş, düzenli bir topluluktur. Geleneksel müzik ile müzikli oyun yazılabileceği 
ilk başta kuşkusu ile karşıllanmıştı. İstanbul Operet Heyeti gerek biçim, gerek öz bakımından geleneksele dönüşü gerçekten ilginç bir deneme olmuştur." (And, 2004: 153).

Müzikli oyunlara ve operetlere "temsili musiki”, üvertüre "küşad musikisi”, koroya "cumhur terennümü", sırayla arya, duo, trio, kuatutor, kentet için de "birli, ikili, üçlü, dörtlü, beşli terennüm", ara orkestra müziğine "sahne musikisi", finale "hitam musikisi", orkestra şefine "müdür", primadonnaya "baş muganniye" denen bu toplulukta, kültürleşmenin içselleştirilip, dönüştürülmesi örnekleri verilir (And, 2004: 153-154).

\section{Muhlis Sabahattin Ezgi (1889-1947)}

Batı müziğini örnek alarak operetler bestelemiştir ve tiyatro toplulukları kurmuş, turnelere çıkmış, temsiller vermiştir. Ayrıca, Türk müziğinin armonize edilemeyeceğini söyleyenlere aldırmayıp, bu yönde de çalışmıştır. Aşk Mektebi adlı opereti buna örnektir ve Şehir Tiyatrosu'nda oynanmıştır (Rona, 1960: 224), (Papazyan, 1975: 24-25).

Muhlis Sabahattin, Muhlis'in Çocukları adlı topluluğu kurduktan sonra, bu topluluk Süreyya Opereti'ne dönüşür. Bu yeni operetin temsillerinde Ayşe opereti ile Suzan Lütfullah ünlenirken, Muhlis Sabahattin de "operet kralı" olarak anılmaya başlar. Müzikli oyun ve operet besteleri: Çaresaz, Aşk Mektebi, Kerem ile Asl, Gül Fatma (Halk Opereti Topluluğu'nca oynanmıştır), Zühre, Asaletmaap, Zehra, Dersaadet, Perde Arkası (Halk Opereti Topluluğu'nca oynanmıştır), Monbey, Kadınlardan Bıktım (Halk Opereti Topluluğu'nca oynanmıştır), Muteber, Hatırım İçin (Papazyan, 1975: 25).

Yukarıda kısa biyografileri verilen ulusal operet temsilcilerinden sonra, batı müziği sisteminin kurallarına göre operet bestelemeyle karşılaşılır. Batı müziği tonlarına yakın duyumu olan makamların armonize edilmesiyle başlayan bu müziksel değişiklik, gittikçe içinde Türk müziğine ait motiflerin azaldığı operet şarkılarına ve batılı operet besteciliğine yol açar.

\section{Türkiye'de Operet Toplulukları}

Dikran Çuhaciyan'ın kurduğu Osmanlı Opera Tiyatrosu'ndan sonra, çeşitli tiyatro türlerinin temsillerini veren toplulukların yanı sıra, yalnızca operet temsili vermek amacıyla kurulan topluluklar da kurulmaya başlamıştır. Meşrutiyet döneminden (1908) itibaren kurulan bu topluluklardan ayrıntılı olarak bahsetmek, çalışmanın odağından uzaklaşmak ve makalenin hacmini arttırmak anlamına geleceği için, bu bölümde toplulukların isimlerine ve kısa bilgilerle kronolojik sıralamasına yer verilecektir.

Meşrutiyet döneminde kurulmuş bazı operet toplulukları, Cumhuriyet döneminde de varlığını sürdürmüştür: Hale Opereti, Şehir Operet Heyeti, İstanbul Şehir Opereti (1927'de kurulmuş, İstanbul Belediyesi ile ilgisi olmayan Darülbedayi'den ayrllan bazı sanatçllarca kurulan topluluk (And, 2015: 260), Türk Opereti, Yeni Operet Heyeti, Şark Opereti, Ankara Opereti, Cumhuriyet Opereti. Bu topluluklardan Şark Opereti, 1928'de kurulmuş olan Türk Opereti'nin oyuncularından Cemal Sahir ile Nıvart (Nuvart) Hanımın birleşmesinden sonraki adıdır. Diğerleri ise; Meşrutiyet döneminden beri temsil veren topluluklar olup, temsillerine Cumhuriyet döneminde de devam ederler.

1924 yılında, Raşit Rıza'nın topluluğu olan Türk Tiyatrosu (Meşrutiyet döneminde kurulmuş, temsillerine Cumhuriyet döneminde de bir süre daha devam etmiş bir topluluk), 1925'e de uzanan ve Ferah Sezonu olarak 
tanımlanan kısa bir dönem temsil verir. Aynı dönem Ertuğrul Muhsin ve Arkadaşları adlı topluluğa da rastlanmaktadır. Ayrıca yine bu dönem içerisinde, Şehbal Opereti, Naşit'in Topluluğu, gibi topluluklar da çalışmalar yapmıştır. Bu yıllarda 1923'ten beri temsillerini sürdüren en tutarlı topluluk, Şadi Fikret'in Milli Sahne adlı topluluğudur (And, 1973: 193). 1925 senesinde karşımıza çıkan topluluklar ise; İstanbul Operet Heyeti, Kel Hasan'ın Şark Tiyatrosu, Yeni Operet Heyeti, Naşit'in toplulukları olmuştur.

1924-1925 döneminde, tiyatro adına en parlak dönem olarak belirtilen ve topluluğun Ferah Tiyatrosu'nda temsil vermesinden yola çıkılarak, temsil verdiği sezona Ferah Sezonu denen Muhsin Ertuğrul ve Arkadaşları (Ertuğrul Muhsin ve Arkadaşlarl) adlı topluluk, en düzenli topluluk olarak görülür (And, 2015: 259).

1926 yılına gelindiğinde, Türk Dram Kumpanyası, İsmail Dümbüllü'nün Topluluğu, Sahir Opereti adlarıyla karşılaşılmaktadır.

1927'de Asri Operet Heyeti, Sahir Opereti, İsmail Dümbüllü'nün Topluluğu, Şehir Tiyatrosu isimlerine rastlanırken, 1928'de, bu isimler içinden adına en çok rastlanan Şehir Tiyatrosu olmuştur (Darülbedayi). Sahir Opereti'nde Cemal Sahir de operet temsillerini aynı yıl sürdürürken, Ankara Opereti ile birleşmiş̧ir. Süreyya Opereti de 1928 y1lının en düzenli operet topluluğu olmuştur. Süreyya Opereti 1928 yılında Süreyya Paşa'nın maddi desteğiyle kurulan topluluk, Süreyya Sineması'nda temsiller vermiştir. Muhlis Sabahattin Ezgi, Lütfullah Sururi, Celal Sururi, Reşit Gürzap, Şevkiye May, Toto Karaca ve Semiha Berksoy gibi dönemin en ünlü sanatçılarının oluşturduğu topluluk, genellikle Muhlis Sabahattin Ezgi'nin operetlerini oynar (Çaresaz, Ayşe gibi). Uyarlama operetler de oynayan topluluk, yerli operetlere dikkat çekmek, halkı yerli operetlere alıştırmak açısından önemli bir işlevi yerine getirerek, Darülbedayi'nin kurulmasına öncülük etmiş sayılmaktadır. Topluluk 1935 yılında, Süreyya Paşa'nın parasal desteğini topluluktan çekmesinin ardından yaşanan maddi sıkıntılar yüzünden dağılır. Topluluk, aynı kadroyla ismini değiştirerek, topluluğun son ilanının içinde ismi geçen ve çalışmamızın odak noktasında olan Halk Opereti Topluluğuadıyla varlığını sürdürür (Kutluk, 1989: 9).

1929 yılına geldiğimizde, Ankara Güneşi Temsil Heyeti, Naşit'in topluluklarl, Ankara Temsil Heyeti ve İnkılap Tiyatrosu isimli topluluklar da temsil vermiştir.

1930'da Şehir Opereti, Türk Akademi Tiyatrosu (T.A.T.) var iken, 1931'de Sahir Opereti, Muhlis'in Çocukları Operet Heyeti, Şevki Bey Topluluğu, Şanit Bey Topluluğu, Asri Gençler Temsil Heyeti, Süreyya Opereti, Sahir Opereti, Naşit'in Topluluğu ile operet temsilleri sürmüştür (And, 1973: 213).

1932 yılında Raşit Rıza'nın topluluğu çalışmalarına devam ederken, Darülbedayi'de ilk defa operet temsillerine başlanmıştır (And, 1973: 213).

1934 yılında Darülbedayi'nin adı Şehir Tiyatrosu olmuştur. Raşit Rıza Topluluğu, İstanbul Şehir Tiyatrosu gibi farklı adlarda topluluklara da rastlanmaktadır. Yine bu yıl, Ankara'da Milli Musiki ve Temsil Akademisi'nin kurulması da önemli bir gelişmedir (And, 2015: 277).

1934'te, Ankara'da Güzel Sanatlar Genel Müdürlügü̈ kurulur (And, 2015: 277). Yine bu yıl Ozan Opereti adlı topluluğa rastlanır. Muhlis Sabahattin Ezgi'nin Fahri Güldürür ve İsmail Dümbüllü ile birleşerek kurduğu topluluk, kısa ömürlü olur ve aynı yıl dağılır(Kutluk, 1989: 9).

1935'in sonlarına gelindiğinde Süreyya Opereti'nin adı Halk Opereti olur ve Halk Opereti çalışmalarına bu yıl başlar ve devam eder. Ozan Opereti, 1935 yılında Çaresaz, La Maskot (Maskot, Halk Opereti Topluluğutarafindan 
da daha sonra oynanır),Tarla Kuşu(Halk Opereti Topluluğutarafindan daha sonra oynanır), Leblebici Horhor(Halk Opereti Topluluğutarafindan daha sonra oynanır), Karım Namusludur (Halk Opereti Topluluğutarafindan daha sonra oynanır) ve Mon Bey operetlerini oynar (And, 2015: 322). 1935 y1lında İstanbul Şehir Tiyatrosu'nda bir yenilik olarak çocuk tiyatrosu oyunları oynanmaya başlanır (And, 2004: 187). Buna ek olarak, Şehir Tiyatrosu 1935'te Fransız Tiyatrosu'nda operet, Tepebaşı Tiyatrosu'nda dram ve komedi, Asri Sinema'da ise çocuk oyunları olmak üzere üç tiyatroda temsillerine devam eder (And, 2015: 271). Raşit Rıza'nın topluluğundan ayrılan Halide Pişkin, 1935 yılında Halide ve Arkadaşları adlı bir topluluk kurar.

1936'da da Kadın Birliği adında bir operet topluluğu kurulur fakat; uzun süre varlık gösteremez. Ertuğrul Sadi Tek topluluğu T.A.T. adı altında 1935 yılında kurulur ve Halk Opereti Topluluğu'nun ilanlarıla alt alta ilanlar verdiği, gazete kupürlerinde görülmektedir. Muhlis Sabahattin 1935 yılında Yeni Operet topluluğunu kurar ve bu topluluk Süreyya Opereti ile daha sonra birleşir (And, 2015: 322).

1935 yılının diğer önemli gelişmesi de, Ankara'da Devlet Konservatuvarı Tatbikat Sahnesi'nin opera ve tiyatro gösterimlerinin başlamasıdır. 1947 yılına dek Tatbikat Sahnesi'nin başında bulunan Carl Ebert Türkiye'den ayrılır ve kuruluş aşamasında olan Devlet Tiyatro ve Operası'nın başına Muhsin Ertuğrul getirilir. Devlet Tiyatrosu Kuruluş Kanunu'nun çıkmasıyla 1949 yılında, Türkiye'nin içinde opera ve bale kolu da bulunan, Devlet Konservatuvarı'ndan doğan bir Devlet Tiyatrosu olur (And, 2004: 172-173).

1938 yılında, İstanbul Halk Tiyatro ve Revü Topluluğu kurulur, Muhlis Sabahattin aynı yıl Türk Opereti'ni kurar. 1939 yılında Türk Revü Opereti kurulur (And, 2015: 322-323).

1940 yılının en önemli olayı, tiyatro yaşamı pek olmayan Ankara'da, Devlet Konservatuvarı Tatbikat Sahnesi'nin kurulmasıyla opera ve tiyatro gösterimlerine başlanmasıdır. 1949 yılına kadar gösterimler devam eder. 1940 yılının bir diğer önemli olayı da Avni Dilligil tarafından yapılan girişimlerle Ses Tiyatrosu Operet Topluluğu'nun kurulması olur ve bu topluluk 1955 yılına kadar farklı isimler altında ve farklı kadrolarla çalışmalarını sürdürür (And, 2004: 187).

1943 yılında Avni Dilligil, Ses, Dram, Komedi ve Operet Topluluğu'nu kurar. Bu durumda Ses, Dram, Komedi ve Operet Topluluğu, Ses Tiyatrosu Operet Topluluğu'nun dağılana kadarki süreçteki isimlerinden biridir.

1944 'te Yeni Halk Opereti kurulur, Ses Opereti'nde kadroda değişiklikler olurken Ses Opereti,Yeni Ses Opereti adını alır ve aynı zamanda Muhlis Sabahattin'in Türk Opereti adlı topluluğu da temsillerine devam eder.

1945 'te Atilla Revü Operet Topluluğu kurulur ve bu dönemde Muammer (Ruşen) Karaca, Ses Opereti'nden ayrılarak, isminin baş harflerinden oluşan Merka Operet Topluluğu'nu kurar.

1946 yılına gelindiğinde de Ses Opereti çalışmalarına devam ederken, Atilla Revüsü ve Merka Operet Topluluğu da aynı şekilde çalışmalarına devam eder. Toto ve Sitkı Akçatepe Topluluğu, bu yılın tek farklı topluluğu olur (And, 2015: 323). 1947'den itibaren Yeni Ses Opereti olarak çalışmalarına devam eden topluluk, 1955'te Şen Ses Opereti ismini alır.

1947 yılında bir değişiklik daha olur ve Muammer Karaca operet temsillerini bırakıp, tiyatro oynamaya başlar (And, 2015: 324). 
1954 yılında, Tevhid Bilge Operet Heyeti ve İstanbul Opereti kurulur. Aynı dönemde, Devlet Tiyatrosu'nda Amerikan müzikli komedileri oynanmaktadır. Tam anlamıyla müzikli oyun sayılamayacak nitelikteki oyunlara da müzikli oyun veya operet denmeye başlanır (And, 2015: 324).

Halk Opereti Topluluğu'nun dağıldığg yıl kabul edilen 1953'e kadarki yıllar, Türkiye'de operet topluluklarının kurulup, dağıldığı yıllardır. Tüm bahsi geçen topluluklar, özel operet toplulukları olup, çoğunun oyuncu kadrosu, başka bir toplulukla birleştiğinden, aslında dönemin belli başlı oyuncularının adeta sadece bulunduğu topluluğun adı değişmiştir. Operet topluluklarını o dönemde seyretmeye giden biri için, sahnede hep aynı sanatçılar temsil vermekteyken, sadece topluluğun veya temsilin adları değişmiştir. Toplulukların dağılmasının da yegane sebebi, maddi sıkıntılar yaşanması, ideolojik sebepli anlaşmazlıkların olmasıdır.

\section{Halk Opereti Topluluğu}

Halk Opereti Topluluğu, ilk temsilini 11 Kasım 1935'te, metni Mahmud Yesari ve Necdet Rüştü'ye, bestesi Seyfettin ve Sezai Asaf kardeşlere ait olan Bay Bayan adlı operet ile Fransız Tiyatrosu'nda vermiştir. Söz konusu operetin afişi, Süreyya Opereti'nin temsilinin ilan olunduğu afişte yer almıştır (Cumhuriyet Gazetesi, 08111935 : 4). Halk Opereti Topluluğu, Süreyya Opereti'nin kurucularından Lütfullah Sururi tarafından Süreyya Opereti'nin kadrosunun büyük çoğunluğuyla oluşturulmuş bir devam topluluğudur. Süreyya Opereti'nin isim değiştirerek yoluna devam ettiği de söylenebilir ki bunun sebebi de, Süreyya Opereti'nin en büyük destekçisi olan Süreyya Paşa'nın desteğini topluluktan çekmesi üzerine topluluğun belediyeye aktarılan Süreyya Sineması'na olan borcu olduğu görülür (Cumhuriyet Gazetesi, 0307 1934: 4).

Halk Opereti Topluluğu, bir tiyatro dönemi boyunca çok sayıda yeni operet temsili ile halk karşısına çıkmıştır. Sevilen eski operetlerin yanı sıra yeni operetleri de sahneye koyan toplulukta, orkestra şefi ve kompozitörü Karlo Kapoçelli olmuştur. İtalya'da batı müziği eğitimi almış ve Darülbedayi'de de uzun yıllar görev almış olan Karlo Kapoçelli dışında Yunan aktrist Zozo Dalmas ve Yunan tenörler de Halk Opereti Topluluğu kadrosunda bulunmuş önemli isimlerdendir. Ayrıca; topluluğun operet temsillerinin öncesi veya sonrasında konser, revü gösterisi, tuluat v.b. gibi farklı sanat türlerinde gösterimler yapılmıştır ve bu gösterimlerde topluluk ile birlikte sık sık aynı sahneyi paylaşan bazı önemli kişiler şunlardır: Denizkızı Eftalya Sadi, Safiye Ayla, Naşit Özcan (Adile-Selim Naşit'in babası, ünlü tuluat sanatçısı), Fikriye Şakrakses (plağa ses kaydı yapılan ilk Müslüman kadın ses sanatçısı), Halide Pişkin, Necla Sertel (Darülbedayi tiyatro topluluğunda ilk Müslüman kadın oyunculardan), Şaziye Kemal Gürmen (Hüseyin Kemal Gürmen adlı tiyatro oyuncusunun eşi, sahneye ilk çıkan Müslüman kadın oyunculardan). Bunlara ek olarak; topluluğun en sevilen oyuncularından Toto, Cem Karaca'nın annesi iken; Mehmet Karaca (topluluğun bazı operetlerinin yazarı) da babasıdır. Yine bunlara ek olarak; Darülbedayi bir tiyatro topluluğuna dönüştüğünde, Darülbedayi oyuncularından bazıları Halk Opereti Topluluğu'na dahil olmuş, hatta Raşid Rıza Samako da Halk Opereti Topluluğu'nun rejisörlüğüne gelmiştir. Lütfullah Sururi tarafindan kurulan Halk Opereti Topluluğu'nun ilk başlarda en sevilen kadın oyuncusu Suzan Lütfullah, Türkiye'nin ilk Müslüman kadın oyuncularındandır ve Lütfullah Sururi'nin eşidir. Sururi'nin kardeşleri de Halk Opereti Topluluğu'nun kadrosundadır ve ünlü tiyatro oyuncusu Gülriz Sururi de Lütfullah-Suzan Sururi'nin kızlarıdır. (Eskitaş, 2018: 53-111)

Halk Opereti Topluluğu, bir tiyatro binasında temsil vermekle sınırlı kalmamış, aynı zamanda yurdun çeşitli il ve ilçelerine turne kapsamında temsil vermeye girmiş, hatta yardım kuruluşları, sergi, fuar, açılış, anma töreni, jübile gibi pek çok etkinlikte de yer almıştır. Tüm bu oyuncu kadrosu ve programlara bakıldığında, topluluğun döneminin popüler topluluğu olduğu ve popüler isimlerle çalıştığı anlaşılmıştır. 
1935-1953 yılları arasında varlık göstermiş olan Halk Opereti Topluluğu'nun 8 yıl içinde sahnelediği çok sayıda operet olmuştur. Topluluğun sahnelediği bu operetlerin adı, yazarı, bestecisi, oyuncu kadrosu, operetlerin oynandığı mekan, tarih kronolojik olarak bir tablo haline getirilmiştir (Bkz: Tablo 1).

Tablo 1. Halk Opereti Topluluğu Temsilleri

\begin{tabular}{|c|c|c|c|c|c|c|}
\hline \multicolumn{7}{|c|}{$\begin{array}{l}\text { Halk Opereti Topluluğu Temsilleri } \\
\text { (Tablo 1) }\end{array}$} \\
\hline Adı & $\begin{array}{c}\text { İlk Temsil } \\
\text { Tarihi }\end{array}$ & İlk Temsil Yeri & ì & Bestecisi & Yazarı & Oyuncuları \\
\hline Bay bayan & 11.11 .1935 & \multirow{6}{*}{ Fransız Tiyatrosu } & \multirow{12}{*}{ İstanbul } & \multirow{3}{*}{$\begin{array}{c}\text { Seyfettin Asaf } \\
\text { Sezai Asaf }\end{array}$} & \begin{tabular}{|l} 
Mahmud Yesari \\
Necdet Rüştü
\end{tabular} & $\begin{array}{c}\text { Şaziye Moral, Hüseyin K. Gürmen, } \\
\text { Toto Karaca, Nebahat Hanım, } \\
\text { Mehmet Karaca, } \\
\text { Yaşar Nezihi, } \\
\text { Celal Sururi } \\
\end{array}$ \\
\hline Sevda Oteli & - & & & & $\begin{array}{l}\text { Mahmud Yesâri } \\
\text { Yusuf Sururi }\end{array}$ & $\begin{array}{l}\text { Aynı kadroya ek olarak } \\
\text { Lütfullah Sururi }\end{array}$ \\
\hline Telli Turna & 05.01 .1936 & & & & - & Aynı Kadro \\
\hline Deniz Havası & $\begin{array}{c}13.01 .19 \\
36\end{array}$ & & & Karlo Kapoçelli & \multirow[t]{2}{*}{ Yusuf Sururi } & $\begin{array}{c}\text { Aynı kadroya ek olarak, Necla Sertel } \\
\text { Mehmet Karaca }\end{array}$ \\
\hline $\begin{array}{l}\text { Çardaş Fürstin } \\
\text { (uyarlama) }\end{array}$ & - & & & İ. Kalman & & Aynı Kadro \\
\hline Leblebici Horhor & Şubat 1936 & & & $\begin{array}{l}\text { Dikran } \\
\text { Çuhaciyan }\end{array}$ & Takfor Nalyan & $\begin{array}{c}\text { Aynı kadroya ek olarak } \\
\text { Celal Sururi } \\
\text { Nebahat Hanım }\end{array}$ \\
\hline Beyoğlu Çiçeği & 15.02 .1936 & - & & - & \multirow[b]{2}{*}{ Yusuf Sururi } & Aynı Kadro \\
\hline $\begin{array}{l}\text { Şen Dul } \\
\text { (uyarlama) }\end{array}$ & Şubat 1936 & - & & Franz Lehar & & $\begin{array}{c}\text { Aynı kadroya ek olarak } \\
\text { Zozo Dalmas } \\
\text { Kofinyotis }\end{array}$ \\
\hline Halime & 08.01.1936 & $\begin{array}{l}\text { Pangaltı Tan } \\
\text { Sineması }\end{array}$ & & Sakalaridis & - & $\begin{array}{c}\text { Aynı kadroya ek olarak } \\
\text { Necati Bey } \\
\text { Ali Sururi }\end{array}$ \\
\hline $\begin{array}{l}\text { Bayader } \\
\text { (uyarlama) }\end{array}$ & Mart 1936 & - & & - & Yusuf Sururi & Aynı Kadro \\
\hline Şirin Teyze & - & - & & - & Mehmet Karaca & Aynı Kadro \\
\hline Tarla Kuşu & 09081938 & $\begin{array}{c}\text { Taksim Altıntepe } \\
\text { Tiyatrosu }\end{array}$ & & - & Yusuf Sururi & Aynı Kadro \\
\hline Florya & 07.05 .1936 & $\begin{array}{c}\text { Balıkesir Şehir } \\
\text { Tiyatrosu }\end{array}$ & Balıkesir & $\begin{array}{l}\text { Seyfettin Asaf } \\
\text { Sezai Asaf }\end{array}$ & $\begin{array}{l}\text { Nezihe } \\
\text { Muhiddin }\end{array}$ & Aynı Kadro \\
\hline Emir (Seviyor) & 10.01 .1936 & $\begin{array}{l}\text { Tayyare } \\
\text { Sinemas1 }\end{array}$ & Bursa & $\begin{array}{l}\text { Seyfettin Asaf } \\
\text { Sezai Asaf }\end{array}$ & $\begin{array}{c}\text { Mahmud Yesari } \\
\text { Necdet Rüştü }\end{array}$ & Aynı Kadro \\
\hline Ayşe & $\begin{array}{c}\text { Temmuz } \\
1936\end{array}$ & Taksim Bahçesi & İstanbul & $\begin{array}{l}\text { Muhlis } \\
\text { Sabahattin }\end{array}$ & $\begin{array}{c}\text { Muhlis } \\
\text { Sabahattin }\end{array}$ & $\begin{array}{l}\text { Aynı kadroya ek olarak } \\
\text { Melek Hanım }\end{array}$ \\
\hline Rahmet Efendi & - & - & - & - & Yusuf Sururi & Kadro aynı \\
\hline Kırk Yilda Bir & - & $\begin{array}{l}\text { Bebek Aile } \\
\text { Bahçesi }\end{array}$ & İcto & $\begin{array}{c}\text { Muhlis } \\
\text { Sabahattin }\end{array}$ & - & $\begin{array}{c}\text { Aynı kadroya ek olarak } \\
\text { Fehmi, Haluk, Veli, Hicran }\end{array}$ \\
\hline $\begin{array}{c}\text { Pipiça } \\
\text { (uyarlama) }\end{array}$ & 21.11 .1936 & $\begin{array}{c}\text { Maksim Varyete } \\
\text { Tiyatrosu }\end{array}$ & Istanbul & - & Yusuf Sururi & $\begin{array}{c}\text { Aynı kadroya ek olarak } \\
\text { Tomakos } \\
\text { Hulki } \\
\end{array}$ \\
\hline İç İçe & 07.12 .1938 & - & - & $\begin{array}{l}\text { Seyfettin Asaf } \\
\text { Sezai Asaf }\end{array}$ & Yusuf Sururi & $\begin{array}{l}\text { Rejisör: Raşid Riza } \\
\text { Macar Suzi Balet Heyeti }\end{array}$ \\
\hline Enayiler & Aralık 1936 & $\begin{array}{c}\text { Şehzadebaşı } \\
\text { Turan Tiyatrosu }\end{array}$ & İstanbul & - & - & $\begin{array}{c}\text { Aynı kadroya ek olarak } \\
\text { Lebibe } \\
\text { Hulki } \\
\text { Bay ve Bayan Tomakos }\end{array}$ \\
\hline $\begin{array}{l}\text { Eski Hamam } \\
\text { Eski Tas }\end{array}$ & 1937 & - & & - & Mehmet Karaca & - \\
\hline
\end{tabular}




\begin{tabular}{|c|c|c|c|c|c|c|}
\hline Kadınlardan Bıktım & - & $\begin{array}{c}\text { Kadıköy } \\
\text { Miltiyadi } \\
\text { Sinemaları }\end{array}$ & & - & Yusuf Sururi & - \\
\hline Gül Fatma & $\begin{array}{c}\text { May1s } \\
1938\end{array}$ & $\begin{array}{c}\text { Kadıköy Süreyya } \\
\text { Sineması }\end{array}$ & & $\begin{array}{c}\text { Muhlis } \\
\text { Sabahattin }\end{array}$ & $\begin{array}{c}\text { Muhlis } \\
\text { Sabahattin }\end{array}$ & - \\
\hline Perde Arkası & $\begin{array}{c}\text { Mayis } \\
1938\end{array}$ & $\begin{array}{c}\text { Pangaltı Kurtuluş } \\
\text { Tiyatrosu }\end{array}$ & & - & Yusuf Sururi & - \\
\hline Üç yıldız & $\begin{array}{c}\text { May1s } \\
1938\end{array}$ & Azak Tiyatrosu & & - & Yusuf Sururi & - \\
\hline Kına Gecesi & - & $\begin{array}{l}\text { Halk Opereti } \\
\text { Tiyatrosu }\end{array}$ & & Seyfettin Asaf & & - \\
\hline Modern Kizlar & Ocak & $\begin{array}{l}\text { Halk Opereti } \\
\text { Tiyatrosu }\end{array}$ & & - & Mahmud Yesari & $\begin{array}{c}\text { Aynı kadroya ek olarak } \\
\text { Macar Foks Balet Heyeti }\end{array}$ \\
\hline Aşk borsası & & - & - & - & & - \\
\hline Telefoncu Kız & & Taksim Bahçesi & İstanbul & - & - & - \\
\hline Se Yek & 1939 & - & - & $\begin{array}{l}\text { Seyfettin Asaf } \\
\text { Sezai Asaf }\end{array}$ & - & - \\
\hline Zır Deliler & $\begin{array}{c}27.03 .19 \\
39\end{array}$ & \begin{tabular}{|c|} 
Kadıköy Süreyya \\
Sineması
\end{tabular} & İstanbul & - & Yusuf Sururi & - \\
\hline Bu Hesapta Yoktu & $\begin{array}{l}\text { Ekim } \\
1939\end{array}$ & - & - & - & - & - \\
\hline Git Kal (Oteli) & $\begin{array}{c}\text { Kasım } \\
1939\end{array}$ & - & & - & $\begin{array}{c}\text { Yusuf Sururi } \\
\text { Mehmet Karaca }\end{array}$ & - \\
\hline Gönül Belas1 & $\begin{array}{c}25.11 .19 \\
39\end{array}$ & $\begin{array}{l}\text { Halk Opereti } \\
\text { Tiyatrosu }\end{array}$ & İstanbul & Karlo Kapoçelli & Yusuf Sururi & - \\
\hline Kediye Peynir & $\begin{array}{c}27.01 .19 \\
40\end{array}$ & - & - & - & - & - \\
\hline $\begin{array}{l}\text { La Maskot } \\
\text { (uyarlama) }\end{array}$ & 1940 & - & - & Odreau & Yusuf Sururi & - \\
\hline Üç Kuyumcu & $\begin{array}{c}21.02 .19 \\
40\end{array}$ & - & - & - & Yusuf Sururi & - \\
\hline $\begin{array}{l}\text { Yunus Bey } \\
\text { Duymasin }\end{array}$ & $\begin{array}{c}16.03 .19 \\
40\end{array}$ & - & - & - & - & - \\
\hline Çeşm-i Siyah & \multirow{4}{*}{1953} & $\begin{array}{c}\text { Suadiye Şenyol } \\
\text { Çiçek Bahçesi }\end{array}$ & \multirow{4}{*}{ İstanbul } & - & - & - \\
\hline Karım Namusludur & & \begin{tabular}{|c|} 
Kocamustafapaşa \\
Aynur Sineması
\end{tabular} & & - & - & - \\
\hline $\begin{array}{c}\text { Büyük Operet (Adı } \\
\text { verilmemiştir) }\end{array}$ & & $\begin{array}{l}\text { Yeşilköy Röne } \\
\text { Park }\end{array}$ & & - & - & - \\
\hline $\begin{array}{l}\text { Büyük Operet } \\
\qquad \text { (Adı } \\
\text { verilmemiștir) }\end{array}$ & & $\begin{array}{c}\text { Yeşilköy } \\
\text { Röne Park }\end{array}$ & & - & - & - \\
\hline
\end{tabular}

Topluluğun temsilini verdiği operetlerin nota veya ses kaydına ulaşılamadığından, operet eserleri hakkında yapılmış müziksel yorumlar içeren veriler derlenerek, incelenmiştir. Bu tabloda görülmektedir ki (Tablo 1); topluluğun çoğu operetinin bestecisi, Seyfettin ve Sezai Asaf kardeşlerdir. Asaf kardeşler, Batı müziği eğitimi almış, Darülbedayi'nin "Garb Musikisi Bölümü"nde ve daha sonra da Darülelhan'ın "Alafranga" bölümünde akademisyenlik yapmış kişilerdir. Buradan hareketle, topluluğun Seyfettin ve Sezai Asaf kardeşler tarafindan bestelenmiş operet eserleri, batı müziği sisteminin kurallarına göre bestelendiği çıkarımı yapılabilir. Ayrıca; topluluğun yine çoğu operetinin uyarlama olduğu da görülmektedir. Sonuç olarak topluluğun, müziksel yoruma ulaşılabilen birkaç operetinin dışında, batı müziği sisteminin kurallarıyla bestelenmiş operetlerin temsilini veren bir topluluk olduğu söylenebilir.

Muhlis Sabahattin Ezgi'nin, batı müziği sentezine olanak tanıyan ve batı müziğindeki majör-minör tonlara yakın bir duyumu olan makamlara, armonizasyon, sentezleme yaparak bestelediği bazı operetleri de Halk Opereti 
Topluluğu'nun oynadığını biliyoruz. Buna ek olarak, topluluğun müziksel yorumuna ulaşılan birkaç operetinde (Bkz: Tablo 2) "şark motifleri kullanılmıştır" ifadesine de rastlamaktayız. Yani; geleneksel Türk müziği kurallarına uymayan ama bu kurallara yakınlık gösteren birkaç operet temsili verdiğini çıkarımlarla anladığımız topluluk, ancak ve ancak halkı eğlendirmesi bağlamında rağbet görmüş ve akılda kalıc1-basit motiflerle örülü-küçük cümleli müzik yapısına sahip olan bu türde verdiği temsillerle Türk müziği tarihi açısından ve Türk müziğinin geleneksel ve sanatsal katları açısından bir önem arz etmemektedir.

Tablo 2. Halk Opereti Topluluğu'nun Operet Şarkıları Analiz Tablosu

\begin{tabular}{|c|c|c|}
\hline \multicolumn{3}{|c|}{$\begin{array}{l}\text { Halk Opereti Topluluğu'nun Operet Şarkıları Analiz Tablosu } \\
\text { (Tablo 2) }\end{array}$} \\
\hline Operetin Adı & Operet Bestekarı & Operet Hakkında Müziksel Yorum İçeren Veriler \\
\hline Bay Bayan & Seyfettin Asaf Sezai Asaf & $\begin{array}{l}\text { "Parlak ve şakrak bir beste" betimlemesi yapılmıştır. Operet temsilinde zeybek } \\
\text { oynanmıştır (Cumhuriyet Gazetesi, } 0411 \text { 1935: 5). }\end{array}$ \\
\hline Sevda Oteli & \multirow{2}{*}{ Karlo Kapoçelli } & $\begin{array}{l}\text { Operet ve revü türlerinin bir araya getirilmesiyle oluşan bir operettir. "Spor" adlı operet } \\
\text { şarkısı rumba ve tango ritmiyle ve doğu motifleriyle bestelenmiştir. Batı ve doğu müziği } \\
\text { sentezlemesiyle oluşturulmuş bir operet şarkısı içermektedir. Operette, besteli kısımlar } \\
\text { azdır (Cumhuriyet Gazetesi, } 3011 \text { 1935: 5). }\end{array}$ \\
\hline Deniz Havası & & $\begin{array}{l}\text { "Milli motifler üzerine armonize edilmiş" ifadesiyle ilan edilen operetin, operet } \\
\text { eserlerinin çoğu kısmının alaturka motifler içerdiği bilgilerine ulaşılır. Söz konusu } \\
\text { kaynakta, operet şarkılarının çoğu kısmının alaturka motifler içerdiği bilgisine de ulaşı1lır } \\
\text { (Cumhuriyet Gazetesi, } 2001 \text { 1936:9). }\end{array}$ \\
\hline Çardaş Fürstin & Emmerich Kalman & $\begin{array}{l}\text { Uyarlama bir operettir. Dolayısıyla batı müziği kurallarına göre bestelenmiş operet } \\
\text { şarkıları içermektedir. }\end{array}$ \\
\hline Leblebici Horhor (Ağa) & Dikran Çuhaciyan & $\begin{array}{l}\text { Dili Türkçe'dir ve Arif'in Hilesi isimli ilk Türk operetinden sonraki Türk operetidir. Türk } \\
\text { müziği kurallarıla bestelenmiş operet şarkıları içermektedir. Ayrıca; şark dansları } \\
\text { içeren bir operettir. }\end{array}$ \\
\hline Beyoğlu Çiçeği & - & $\begin{array}{l}\text { Yunan operetidir. Bir kısmı Türkçe bir kısmı da Rumca oynanmıştır (Cumhuriyet } \\
\text { Gazetesi, } 1702 \text { 1936: 2). Müziği muhtemelen Yunan müziği ögeleri barındırmaktadır. }\end{array}$ \\
\hline Şen Dul & Franz Lehar & $\begin{array}{l}\text { "Viyana opereti" ifadesiyle ilan edilen operetin (Cumhuriyet Gazetesi, } 2702 \text { 1936: 7), } \\
\text { operet şarkılarının da batı müziği kurallarına göre bestelenmiş olduğu düşünülmektedir. }\end{array}$ \\
\hline Halime & Sakalaridis & $\begin{array}{l}\text { Yunan operetidir. "Şark müziği ile çok rağbet görüyor." ifadesi ile lanse edilmiştir. Doğu } \\
\text { müziği ve doğu dansları içermektedir (Cumhuriyet Gazetesi, } 0803 \text { 1936: 7). }\end{array}$ \\
\hline Bayader & Emmerich Kalman & $\begin{array}{l}\text { Avusturya operetidir ve uyarlanmıştır. O halde, batı müziği kurallarıyla bestelenmiş } \\
\text { operet şarkıları barındırmaktadır. }\end{array}$ \\
\hline Pipiça & - & $\begin{array}{l}\text { Operetin, "Yalelli" isimli bir operet şarkısı içerdiği bilgisine ulaşılmakta, bu bilgiden } \\
\text { hareketle de doğu motifleri içerdiği düşünülmektedir. }\end{array}$ \\
\hline Enayiler & - & $\begin{array}{l}\text { Batı ve doğu müziği senteziyle bestelenmiş operet şarkıları içermektedir. Operette, } \\
\text { tango ve vals türlerinde şarkılar söylendiği bilgisine ulaşılmaktadır (Cumhuriyet } \\
\text { Gazetesi, } 1312 \text { 1936: 6). }\end{array}$ \\
\hline
\end{tabular}

\section{Operet Topluluklarının Türk Müziği Tarihindeki Yeri}

Türkiye'ye operet toplulukları ilk olarak Osmanlı Devleti döneminde, sefaretnameler, yurt dışında görevli elçiler ve Avrupa hayranlığı duyan batılılaşma ideolojisine sahip padişahların yürüttüğü politika sebepli olarak, opera türü ve opera topluluklarının öncülüğüyle gelmiştir. İlk önce kavramsal olarak kültüre işleyen opera da, azınlıkların kurduğu topluluklar ve yurt dışından gelen opera trupları sayesinde saray ve çevresinin kültürüne, daha 
sonra da oluşan yeni opera toplulukları ve bu toplulukların İstanbul'un eğlence merkezi olan Beyoğlu'ndaki yaygın temsilleriyle de halk tabakasının kültürüne girmiştir.

Yenileşme anlamına gelen Tanzimat'ın ilanıyla İstanbul'da pek çok tiyatro binasının açılması ve bu tiyatro binalarından biri olan Gedikpaşa Tiyatrosu'nda müzikli oyunların oynanmaya başlaması, operet türüne giden yolu açmıştır. Dikran Çuhacıyan ile adında "opera" kelimesi olan bir topluluk kurulmuş, ilk olarak Arif'in Hilesi adlı operet türünde bir eser oynanmış, bunun ardından da rekabet oluşunca, Gedikpaşa Tiyatrosu'nda da opera ve operet temsillerine ağırlık verilmeye başlanmıştır. Gedikpaşa Tiyatrosu, Türk tiyatrosunun gelişimi bakımından önemli görülmesinin yanında, Türkçe tiyatro oynanmasından dolayı da önem arz eder. Bunun yanında, ilk operet bestekarı Dikran Çuhacıyan'ın Gedikpaşa Tiyatrosu'nda oynanan ilk Türkçe opereti yazmış olması da önem taşır.

Operet topluluklarının oluşmasına zemin hazırlayan diğer bir etken de sarayın bando takımıdır. Muzıka-yı Humayun'da batı çalgılarının ve batı müziği formlarının çalınması, operet şarkılarına giden yolu açarken, kurumun bir de tiyatro eğitimi veren, sarayda ve dışarıdaki tiyatrolarda temsil verecek sanatçılar yetiştiren bir bölümünün olması, operet topluluklarının temsillerine zemin hazırlamıştır. Ayrıca; bu kurumun, sarayın her türden müzik faaliyetinde görevli olan sanatçılardan oluşması nedeniyle saray ve çevresince batı müziğinin benimsenmesinde önemli rolü olmuştur. Bunun da yanında, Muzıka-yı Humayun, halkın içinde yapılan her türden törende de bulunduğu için, batı müziği formlarından oluşan bir repertuvar seslendirmek suretiyle, halkın bu türlere alışmasını ve benimsemesini kolaylaştırıcı etkisi olmuştur. Kısa bir zaman içinde Osmanlı kültürüne giren batı müziği ve çalgıları, saray içinde bale ekibinin ve kızlardan kurulu kalabalık bir fanfar ekibinin kurulmasına, sarayda batı müziği çalgıları ile Türk müziği çalgılarının birlikte çaldığı toplantı, eğlence, şenlik türünden programlara, saray müzisyenlerinin besteciliğine yansımış, Fasl-ı Cedid ve Şark-ı Cedid türlerinin ortaya çıkmasını kolaylaşmıştır. İlk konservatuvar görevi gören bu kurumdan sonra, Darülbedayi ve Darülelhan gibi iki kurumun doğması, bu kurumlardaki hocalardan bazılarının opera, operet, marş gibi türler bestelemesi, hatta Türk müziği sistemi kurallarıyla bestelenen operetlerin doğuşuyla da Türk Opereti oluşmuştur. Türk Opereti adındaki II. Meşrutiyet döneminde başlayan milli operet besteleme akımı, "Operet Kralı" olarak bilinen Muhlis Sabahattin Ezgi ile batı müziği ve Türk müziği sentezlemesiyle bestelenen operetlere, zaman içinde de batı müziğine daha yakın bestelenen, armonize edilmiş, çokseslilik ögesi barındıran operetler yaratılmasına yol açmıştır. Bu isimlerden Cemal Reşit Rey de, Lüküs Hayat opereti ile ünlenmiş, bu türün ürünlerini vermiş önemli bir operet bestecisi olarak kabul edilmektedir.

Operet topluluklarının kayıtlarının alınması ve bu eserlerin yayılmasını hızlandırmak amacıyla yurt dışından gelip, kayıt cihazlarına operet eserlerini kaydeden yabancılar sayesinde, Türkiye kayıt cihazlarıyla tanışmışıtır. Bu sayede, geleneksel eserlerin aslına uygun geleceğe aktarılması sağlanabilir hale gelmiş, derleme çalışmaları kayıtlar sayesinde kolaylaşmıştır.

Cumhuriyet döneminde M. Kemal Atatürk'ün müzik ile ilgili şu sözleri doğrultusunda yeni atılımlar yapılmıştır:

....Bir ulusun yeni değişikliğindeki ölçü, musikideki değişikliği alabilmesi, kavrayabilmesidir... Ulusal ince duyguları toplamak, onları bir gün önce genel musiki kurallarına göre işlemek gerekir. Ancak bu şekilde Türk ulusal musikisi yükselebilir, evrensel musikide yerini alabilir (Atatürk, 1934). 
Cumhuriyet'in kuruluş döneminde; tiyatro, opera, bale ve çoksesli müzik gibi sanat alanlarında yapılacak gelişmeler, çağdaşlıkla eş kabul edilmiştir. Bu yönde kültürel gelişime katkısı olabilecek pek çok çalışma, taslak hazırlanmış, birer birer yürürlüğe konmuştur. İlk olarak çoksesli müzik çalışmaları, saray bandosu olan Muzıkay1 Humayun’un 1924 yılında Ankara’ya aktarılması ile Cumhurbaşkanlığı Senfoni Orkestrası (Riyaset-i Cumhur Musiki Heyeti) oluşturulmuştur. Aynı yıl, Ankara'da Musiki Muallim Mektebi kurulmuş, Türk Beşleri olarak anılan (Cemal Reşit Rey, Ulvi Cemal Erkin, Hasan Ferit Alnar, Ahmet Adnan Saygun ve Necil Kazım Akses) gençlerin yurt dışına gönderilip, batı müziği eğitimi almaları sağlanarak, döndüklerinde çoksesli müzik alanında önemli gelişmeler yaratmaları sağlanmıştır.

1936 yllında Musiki Muallim Mektebi, konservatuvara dönüştürülmüştür ve Tatbikat Sahnesi’nde opera temsillerine de yer verilmesine önem verilmiştir. 1949 yılında tiyatro, opera ve bale alanlarını bünyesinde bulunduran Devlet Tiyatrosu kurulmuş, bu kurumun bünyesinde bulunan Devlet Opera ve Balesi ise bir bölüm iken 1970 yılında Kültür ve Turizm Bakanlığı’na aktarılarak Devlet Opera ve Balesi Genel Müdürlüğü adını almıştır.

Bütün bu sürece bakıldığında, operet topluluklarının halkın tiyatroya ve tiyatro türlerine alışması bakımından büyük rol oynadığı görülmektedir. Vodvil, revü, operet, opera gibi müzikli tiyatro türlerini izlemeye alışan halk; marş, tango, vals, şarkı gibi batı müziği formlarıyla da tanışmıştır ve Türk müziği kurallarıyla da bestelenen bu türler, içselleştirilmiştir. Yine bu topluluklar, batılı kurum ve kuruluşların Türkiye'de kurulması sürecini de hızlandırmıştır.

\section{Halk Opereti Topluluğu'nun Türk Müziği Tarihindeki Yeri}

Tüm operet toplulukları içindeHalk Opereti Topluluğu'nun yeri Türk müziği tarihinde batı müziğinin yakınındadır. Toplulukta, Türk müziği sisteminden çok, batı müziği ile bestelenmiş operetler ve uyarlama operet şarkıları seslendirilmiştir. Halime opereti gibi bir kaç operet söz konusudur ki (Bkz: Tablo 2), bu operetlerde de doğu müziği (oryantal müzik) motifleri kullanılmıştır.

Halk Opereti Topluluğu, Türk müziğine hizmet etmemiş gibi görünse de, bir önceki başlık altında açıklandığ üzere, Türk müziği tarihi açısından devrim niteliğindeki gelişmelere dolaylı olarak hizmet etmiş sayılır. Batı müziği eğitimi verilen konservatuvarların kurulmasına yardımı olan topluluk, Devlet Opera ve Bale Genel Müdürlüğ̈̈'nün kurulmasına gidecek yolu açan etkenlerden biridir.Operet türünün yaygınlaşması, içselleştirilmesi, dönemin en çok tercih edilen eğlence aracı olması sebebiyle, topluluk halkın popüler müzik ihtiyacını karşılamış, halkın batı müziğine alışmasına katkı sağlamıştır. Döneminin diğer operet topluluklarıyla aynı zincirin farklı halkaları konumundaki Halk Opereti Topluluğu, tüm topluluklarla aynı değerde önem taşır.

\section{Sonuç}

Osmanlı Devleti'nde yönetim şeklinin monarşik olması sebebiyle daha hızlı bir şekilde yürürlüğe konan batılılaşma ideolojisinden, devletin tüm kurum ve kuruluşları etkilendiği gibi kültürel alanda da aynı etkileşim söz konusu olmuştur. İlk olarak askeri alanda batıyı örnek alan devlet adamları, daha sonra saraydaki yaşamlarına dahi batılı kültürü adapte etmiştir. Askeri alanda yapılan batılı anlamdaki değişiklik, batılı bir boru takımı olarak 
Muzıka-yı Humayun'un kurulmasıyla devam etmiş, sonraları bu bando bir konservatuvar haline gelmiş, hatta bu kurumda müzik eğitiminin yanında tiyatro eğitimi de verilmeye başlanmıştır. Kurumda, İstanbul'daki tiyatrolarda da sahne alan tiyatrocular yetiştirilmiş, batı ve Türk müziği dersleri verilmiş, batılı çalgılardan kurulu bandonun ülkenin her türden töreninde batılı türlerde eserler seslendirmesi suretiyle de halk batılı türlere ve çalgılara alışmıştır.

Tüm dünyada, ilk önce halkın üst tabakasına ulaşan opera, daha sonraları halkın her tabakasının ilgi duyduğu bir tür olmuş, daha sonra da üst kültüre hitap eden bir türe dönüşerek, eski kalabalık seyircisini kaybetmiştir. Türkiye’ye baktığımızda da durum batılı ülkelerden farksızdır. Başkanlık sistemine geçildiği günümüz Türkiye'sinde, operet ve opera türlerinin seyirci sayısı, Cumhuriyet dönemine kıyasla daha azdır ve bu türlere rağbet gösteren halk, üst kültüre aittir. Bahsi geçen tüm batılı tiyatro türleri, Türk müziği içinde melez türler oluşturmasından dolayı, Türk müziğine hizmet etmiş sayılmaktadır. Ayrıca; operet şarkılarının kaydedilip, yaygınlaştırılması amacıyla taş plak kayıt sistemi ile tanışılmış olması da, Türk müziği eserlerinin saklanması ve gelecek kuşaklara aktarılmasına yardımcı olmuş, müzik endüstrisinin gelişiminin önünü açmıştır.

Odak noktası olarak ele alınan ve kısa bir süre halkın büyük bir kısmının rağbet ettiği Halk Opereti Topluluğu da, bahsettiğimiz sonuçlardan farklı sonuçlar doğurmamıştır. Topluluğun operet şarkılarının notalarına ulaşılamadığından bir analiz yapılamamış olsa da, topluluğa ait operet şarkıları, gazete kupürlerindeki anlatımlardan faydalanılarak değerlendirilmiş ve genel olarak uyarlama operetler ve Türk ve batı müziğinin sentezinden oluşan melez bir müzik ile bestelenmiş operet şarkılarının kullanıldığı kanısına varılmıştır. Başlı başına bir çığır açmamışsa da, döneminin operet toplulukları ile birlikte halkın batılı sanata alışması bakımından ve operet izleme ihtiyacına cevap verebilmek açısından var olduğu dönem boyunca Halk Opereti Topluluğu'nun, önemli rol oynadığ 1 saptanmıştır. 


\section{Kaynakça/References}

Altar, C. M. (1939, 05, 29). Ankara Radyosu "Opera nasıl doğdu?. 22, Kasım, 2017 tarihinde www.cevadmemduhaltar.com: http://cevadmemduhaltar.com/opera-nasil-dogdu-radyo-konusmasi.html adresinden alındı.

Altar, C. M. (1993a). Opera tarihi - I. Ankara: Kültür Bakanlığı Yayınları.

Altar, C. M. (1993b). Opera tarihi - II (Cilt 2). Ankara: Kültür Bakanlığı Yayınları.

And, M. (1972). Tanzimat ve istibdat döneminde Türk tiyatrosu. Ankara: Türkiye İş Bankası Yayınları.

And, M. (1973). 50 yılın Türk Tiyatrosu. İstanbul: İş Bankası Kültür Yayınları.

And, M. (2004). Başlangıcından 1983'e Türk tiyatro tarihi. İstanbul: İletişim Yayınları.

And, M. (2015). 100 soruda Türk tiyatrosu tarihi . İstanbul: Gerçek Yayınevi.

Atak, P. (2007, Ağustos). Çăgdaş Türk bestecilerinin operalarının incelenmesi (Yayımlanmamış yüksek lisans tezi), T.C. İstanbul Kültür Üniversitesi, İstanbul.

Atatürk, (1934). Devlet Opera ve Bale Genel Müdürlüğü tarihçe, (2010). Erişim Tarihi: 10, Eylül, 2018, https://www.operabale.gov.tr/tr-tr/kurumsal/genelmudurluk/Sayfalar/Tarihce.aspx adresinden alınd1.

Cumhuriyet Gazetesi, (1934, 3 Haziran). Süreyya Paşa Sineması davasını belediye kazandı. Erişim Tarihi: 16 Ağustos, 2018, www.cumhuriyetarsivi.com adresinden alındı.

Cumhuriyet Gazetesi, (1935, 4 Kasım). Tiyatro Köşesi-Bay Bayan Opereti. Erişim Tarihi: 16 Ağustos, 2018, www.cumhuriyetarsivi.com adresinden alınd1.

Cumhuriyet Gazetesi, (1935, 8 Kasım). Fransız Tiyatrosu Süreyya Opereti. Erişim Tarihi: 16 Ağustos, 2018, www.cumhuriyetarsivi.com adresinden alınd1.

Cumhuriyet Gazetesi, (1935, 30 Kasım). Sahne hayatımızda yeni bir varlık "Halk Opereti". Erişim Tarihi: 16 Ağustos, 2018, www.cumhuriyetarsivi.com adresinden alındı.

Cumhuriyet Gazetesi, (1936, 20 Ocak). Halk operetinde güzel bir operet: Deniz Havası. Erişim Tarihi: 16 Ağustos, 2018, www.cumhuriyetarsivi.com adresinden alındı.

Cumhuriyet Gazetesi, (1936, 17 Şubat). Halk operetinde Beyoğlu Çiçeği. Erişim Tarihi: 16 Ağustos, 2018, www.cumhuriyetarsivi.com adresinden alındı.

Cumhuriyet Gazetesi, (1936, 27 Şubat). Halk operetinde "Şen Dul". Erişim Tarihi: 16 Ağustos, 2018, www.cumhuriyetarsivi.com adresinden alınd1.

Cumhuriyet Gazetesi, (1936, 08 Mart). Halk operetinde: Halime. Erişim Tarihi: 16 Ağustos, 2018, www.cumhuriyetarsivi.com adresinden alındı.

Cumhuriyet Gazetesi, (1936, 13 Aralık). Temaşa Köşsesi-Halk Opereti Müsameresinde Enayiler. Erişim Tarihi: 16 Ağustos, 2018, www.cumhuriyetarsivi.com adresinden alındı.

Ertekin, S. (2007). Türk operasının gelişim süreci. T.C. Başken Üniversitesi Sosyal Bilimler Enstitüsü Müzik ve Sahne Sanatları Anabilim Dalı Müzik Bilimi Yüksek Lísans Programı (Yayınlanmış Yüksek Lisans Tezi). Ankara: Başkent Üniversitesi.

Eskitaş, N. (2018). Halk Opereti Topluluğu ve Türk müziği tarihindeki yeri (Yayımlanmamış yüksek lisans tezi), Ege Üniversitesi, İzmir.

Kutluk, F. (1989). Darülbedayi'deoOperet (Yayımlanmamış yüksek lisans tezi), Dokuz Eylül Üniversitesi, İzmir. Özcan, N. (1993). TDV İslam Ansiklopedisi "Darülelhan" maddesi (Cilt 8). 
Özcan, N. (2006). Muzıka-ı Humayun maddesi (Cilt 31). İstanbul: Türkiye Diyanet Vakfi Yayın Matbaacılık ve Ticaret İşletmesi.

Papazyan, H. (1975). 100 yllda Türk opereti, (1872-1972). İstanbul: Oya Matbaası.

Rona, M. (1960). 50 Ylllık Türk Musikisi. İstanbul: Türkiye Basımevi.

Saz, L. (2000). Anılar 19. Yüzyılda Saray Haremi (2. Bası b.). (Ş. S. Sılan, Çev.) İstanbul: Cumhuriyet Kitap Klubü.

Saz, L. (tarih yok). Harem'in içyüzü. (S. Borak, Dü.) Milliyet Yayınları.

Sevengil, R. A. (1959). Eski Türklerde dram san'atı. İstanbul: Maarif Basımevi.

Sevengil, R. A. (1961). Tanzimat Tiyatrosu. İstanbul: Milli Eğitim Basımevi.

Sevengil, R. A. (1962). Saray Tiyatrosu. İstanbul: Milli Eğitim Basımevi.

Sevengil, R. A. (1969). Opera Sanatı ile ilk temaslarımız. Türk Tiyatrosu Tarihi II. İstanbul: Milli Eğitim Basımevi.

Sevengil, R. A. (2013). İstanbul nasll eğleniyordu? (1453'ten 1927'ye kadar). İstanbul: Alfa Basım Yayım Dağıtım San. Tic. Ltd. Şti.

Şenocak, E. (tarih yok). Taş plaklardan Türk operetlerinin tespiti. 669 - 680.

Toker, H. (2016). "Elhân-ı Aziz" Sultan Abdülaziz Devrinde sarayda mûsikî. İstanbul: TBMM Milli Saraylar Yayın ve Basımevi.

Utku, A. (2005). Lüküs Hayat Operetinin çağdaş Türk Müziği'ndeki yeri ve önemi (Yayımlanmamış yüksek lisans tezi), Ege Üniversitesi, İzmir.

Uygun, M. (2010, Aralık). 20. Yüzylldan günümüze müzikal tiyatronun gelişimi ve opera ile etkileşimi (Yayımlanmamış yüksek lisans tezi), İstanbul Teknik Üniversitesi, İstanbul.

Yener, F. (1991). Müzik klavuzu. İstanbul: Bilgi Yayınevi.

Yöre, S. (2008). Osmanl1- Türk Müzik kültüründe Levanten müzikçiler. Türkiyat Araştırmaları Dergisi (24), 413437.

Yöre, S. (2011). Kültürleşmenin bir parçası olarak Osmanlı'da operanın görünümü. Zeitschrift für die Welt der Türken (Türk Dünyası Dergisi) , 53-69. 